\title{
Antioxidant activity of yogurt made from milk characterized by different casein haplotypes and fortified with chestnut and sulla honeys
}

\author{
Annamaria Perna, ${ }^{1}$ Immacolata Intaglietta, Amalia Simonetti, and Emilio Gambacorta \\ School of Agricultural, Forestry, Food and Environmental Sciences, University of Basilicata, Potenza, Viale dell'Ateneo Lucano 10 - 85100 , Italy
}

\begin{abstract}
The aim of this work was to evaluate the antioxidant activity of yogurt made from milk characterized by different casein $(\mathrm{CN})$ haplotypes $\left(\alpha_{\mathrm{s} 1^{-}}, \beta-, \kappa-\mathrm{CN}\right)$ and fortified with chestnut and sulla honeys. The CN haplotype was determined by isoelectric focusing, whereas antioxidant activity of yogurt was measured using 2,2'-azino-bis-3-ethylbenzothiazoline-6-sulfonic acid and ferric-reducing antioxidant power. The statistical analysis showed a significant effect of the studied factors. The results showed that chestnut honey presented the highest phenolic acid and flavonoid contents, which are closely associated with its high antioxidant activity. The antioxidant activity of fortified yogurt samples was affected both by different CN haplotypes and by type of honey added. Yogurts fortified with chestnut honey showed higher antioxidant activity than those fortified with sulla honey. The different behavior observed among the fortified yogurts led us to hypothesize that the effects of protein-polyphenol complex on antioxidant activity are interactive. The results suggest that milk proteins polymorphism and polyphenols play different roles in affecting the bioavailability and the antioxidant activity of yogurt.
\end{abstract}

Key words: yogurt, honey, casein haplotype, antioxidant activity

\section{INTRODUCTION}

Yogurt's popularity is linked to both health benefits and texture resulting from the product's preparation, in line with consumer tastes and needs. Known since ancient times, yogurt is a fermented product, generally obtained from cow milk, and it represents the final result of milk protein coagulation due to the lactic acid produced by both Streptococcus thermophilus and Lactobacillus delbrueckii ssp. bulgaricus (Robinson, 2003). Yogurt with no added flavor is predominantly sour; therefore, to make it more palatable, fruit, flavorings,

Received December 17, 2013.

Accepted August 4, 2014 .

${ }^{1}$ Corresponding author: anna.perna@unibas.it and sweeteners are added to improve flavor balance (Kagan, 1985) and to partly mask acetaldehyde flavor (Bills et al., 1972).

As a frequently used sweetener in fermented dairy products, honey (Chick et al., 2001) can be considered a natural syrup, containing primarily fructose (38.5\%) and glucose (31.3; Ustunol and Gandhi, 2001), with flavorings arising from flower essences. Many authors have reported the inhibitory effects of honey against lactic acid bacteria (LAB; Ćurda and Plocková, 1995; Roumyan et al., 1996), which are due to the high sugar concentration, relatively high acidity, and presence of both organic acids and low concentrations of hydrogen peroxide (Roumyan et al., 1996; Mundo et al., 2004). Recently, other authors (Sanz et al., 2005; Ezz El-Arab et al., 2006) showed that, when used at suitable levels, honey does not inhibit the growth of common bacteria, and could be used as a sweetener and a useful preservative agent in dairy products (Chick et al., 2001; Varga, 2006).

Yogurt and honey are now considered functional foods. In fact, it has been amply demonstrated that their consumption has beneficial effects on health. Previous research showed that some qualities of yogurt, such as its antioxidative, antithrombotic, antimicrobial, immunomodulatory, ion binding, opioid antagonistic activities, or angiotensin-converting enzyme inhibitory qualities, have beneficial effects on bodily functions in humans (Pattorn et al., 2012). In particular, the antioxidant activity of whey and casein proteins in yogurt could be related to their high tendency to chelate metals (Tong et al., 2000; Rival et al., 2001) and to their ability to donate electrons and atoms (Colbert and Decker, 1991). The antioxidant activity of yogurt is influenced by bacterial fermentation that leads to the release of several of bioactive peptides and the relationship between antioxidant activity and concentration of low-molecular weight peptides has been reported in many studies (Kudoh et al., 2001; Virtanen et al., 2007; Gomez-Ruiz et al., 2008). Galleher et al. (2005) reported that the antioxidant capacity is conditioned also by the heat treatment undergone by the milk for the manufacture of yogurt $\left(95^{\circ} \mathrm{C}\right.$ for $\left.15 \mathrm{~min}\right)$ because the denaturation of proteins exposed initially 
buried reactive sites. Moreover, the antioxidant activity is strongly influenced by strain-specific characteristics of LAB (Kudoh et al., 2001; Ryhanen et al., 2001; Hernández-Ledesma et al., 2005; Virtanen et al., 2007; Gupta et al., 2009). In a recent report, Perna et al. (2013a) observed that the antioxidant activity of yogurt made from cow milk was significantly influenced by the casein haplotype. This could be due to specific amino acid sequence of the milk protein variants. In support of this, Minervini et al. (2003), in sodium caseinates of milk from different species, reported that the degree of heterogeneity of $\mathrm{CN}$ may influence the released of peptides formed during proteolysis.

Honey is a natural inert sugar dissolved in around 14 to $20 \%$ of water, with minor amounts of organic acids, along with traces of minerals, vitamins, flavonoids, and phenolic acids. These components define its role as a nutritional source of natural antioxidants responsible for protecting human health (Gheldof and Engeseth, 2002; Gheldof et al., 2002). Honey's therapeutic importance as a known antibacterial agent has been revalorized, as well as its antioxidant, anti-inflammatory, and antitumoral properties were demonstrated (Tonks et al., 2001; Orsolic et al., 2005). The antioxidant activity of honey depends largely on its chemical composition, such as flavonoids, some enzymes (glucose oxidase, catalase and peroxidase), ascorbic acid, Maillard reaction products, organic acids, amino acids, and proteins (Gheldof and Engeseth, 2002; Al-Mamary et al., 2002; Aljadi and Kamaruddin, 2004). Many authors found a strong correlation between antioxidant capacity and phenol content (Gheldof and Engeseth, 2002; Beretta et al., 2005; Meda et al., 2005; Blasa et al., 2006). Phenolic compounds are synthesized by plants as secondary metabolites which, in many cases, serve in plant defense mechanisms to counteract reactive oxygen species (Peterson and Dwyer, 1998; Robards et al., 1999; Wollgast and Anklam, 2000). The phenolic content in honey depends on the floral source which markedly influences the antioxidant activity (Perna et al., 2012).

Few researchers have focused on the effect of fortifying yogurt with honey (Varga, 2006; El-Baz and Zommara, 2007; Abd El-Rahman and Salama, 2008). However, in the scientific literature, no reports are available on the antioxidant capacity of yogurt made from milk with different casein haplotype and fortified with honey. The aim of the present work was to evaluate the antioxidant activity of yogurt made from milk characterized by different $\mathrm{CN}$ haplotypes $\left(\alpha_{\mathrm{s1}}{ }^{-}, \beta-, \kappa_{-} \mathrm{CN}\right)$ and fortified with chestnut and sulla honey. Sulla (Hedysarum spp.) and chestnut (Castanea sativa) honeys are produced widely in southern Italy and represent a large portion of the annual honey production in this area.

\section{MATERIALS AND METHODS}

\section{Chemicals and Apparatus}

The 2,2'-azino-bis-(3-ethylbenzothiazoline-6-sulfonic acid) (ABTS), 2,4,6-tripyridyl-s-triazine (TPTZ), potassium persulfate, hydrochloric acid, ferric chloride, iron(II) sulfate heptahydrate, sodium phosphate, sodium hydroxide, phosphoric acid, acetic acid, 2-mercaptoethanol, urea, $\mathrm{N}, \mathrm{N}, \mathrm{N}^{\prime}, \mathrm{N}^{\prime}$-tetramethylethylenediamine, ammonium persulfate, and sodium acetate were purchased from Sigma-Aldrich (Milan, Italy). Acrylamide, bis-acrylamide, and ampholine buffer were purchased from GE Healthcare Amersham Bioscience (Buckinghamshire, UK). Coomassie Brilliant blue G250 was purchased from Bio-Rad (Richmond, CA). Lactobacillus delbrueckii ssp. bulgaricus and Strep. thermophilus were purchased from Insao s.r.l. (Liscate, Milan, Italy). The spectrophotometer UV-VIS Spectrophotometer 1204 (Shimadzu, Japan) was used. The apparatus for isoelectric focusing Multiphor II Electrophoresis System (Pharmacia LKB, Uppsala, Sweden) was used.

\section{Milk Sample}

This study was conducted on an intensive farm, consisting of more than 350 Italian Holstein and Italian Brown cattle, in the countryside of Potenza, in southern Italy. Before starting the test, about 200 animals in lactation were identified by isoelectric focusing (IEF) to define their haplotypes. Haplotypes were formed by the combination to the individual allelic loci aggregated by $\alpha_{\mathrm{s}^{-}}, \beta-$, or $\kappa-\mathrm{CN}$. After the definition of individual phenotypes, the cows were grouped by haplotype to obtain more consistent milk, which is needed to manufacture yogurt. Overall, the average of the milk total solids and protein was 13.11 and $3.51 \%$, respectively. Yogurt was obtained with a specific yogurt starter culture consisting of a mixture of 2 species of LAB, Strep. thermophilus, and $L b$. delbrueckii ssp. bulgaricus and incubated at $4^{\circ} \mathrm{C}$ for $24 \mathrm{~h}$.

\section{Honey Samples}

Chestnut and sulla honey samples from southern Italy were collected directly from beekeepers during the 2010 harvest (250 g each). The honey purity was carefully checked by pollen analysis carried out according to DIN 10760 (DIN, 2002; Von der Ohe et al., 2004). On the basis of this analysis, the predominant pollen type was Hedysarum spp. (frequency $=>50 \%$ ) and Castanea sativa (frequency $=75-90 \%$ ) for sulla and chestnut honeys, respectively. Honey samples were stored at 
$4^{\circ} \mathrm{C}$ in the dark until analyzed. The experiments were performed using freshly prepared $10 \%$ honey solutions in distilled water. A sugar analog (80\% sugar, wt/vol), serving as a blank, was prepared by dissolving $0.2 \mathrm{~g}$ of sucrose, $0.8 \mathrm{~g}$ of maltose, $4 \mathrm{~g}$ of fructose, and $3 \mathrm{~g}$ of glucose in distilled water to make a solution with $10 \mathrm{~mL}$ of final volume (White, 1979). The antioxidant activity was calculated by subtracting the obtained values for the blank from that of each sample. All tests were performed in triplicate.

\section{Sample Preparation for IEF}

Individual milk samples, kept at $4^{\circ} \mathrm{C}$, and defatted by centrifugation $\left(3,000 \times g\right.$ for $30 \mathrm{~min}$ at $\left.4^{\circ} \mathrm{C}\right)$; the fat layer was solidified at $-20^{\circ} \mathrm{C}$ for $20 \mathrm{~min}$ and removed. Casein was prepared by isoelectric precipitation at $\mathrm{pH}$ 4.6 with $10 \%$ ( vol/vol) acid acetic and $1 M$ sodium acetate at room temperature. After centrifugation at $3,000 \times g$ for $10 \mathrm{~min}$ at $4^{\circ} \mathrm{C}$, the $\mathrm{CN}$ pellet was washed twice with distilled water and stored at $-20^{\circ} \mathrm{C}$. The whole CN was dissolved in $9 M$ urea and 1\% 2-mercaptoethanol for IEF analysis, according to Aschaffenburg and Drewry (1959).

\section{Genetic Variants of CN by IEF}

The genetic variants of the different $\mathrm{CN}$ by IEF were determined according to the method of Trieu-Cuot and Gripon (1981). The IEF analysis was performed on polyacrylamide gel (5\% acrylamide and $0.15 \%$ bisacrylamide) with a thickness of $1 \mathrm{~mm}$ and $2 \%$ carrier ampholytes to create a gradient of $\mathrm{pH} 2.5$ to 10.0 . Gel was prefocused at a constant value of $0.35 \mathrm{~W} / \mathrm{mL}$ of gel and at the maximum limit of 1,200 V. The gel was stained in Coomassie blue G-250 according to Blakesley and Boezi (1977). Haplotype frequencies were determined by the ratio of the number of each haplotype to the total number of haplotypes $\left[\%=\left(\mathrm{n}_{i, \text { haplotype }} / \mathrm{n}_{\text {tot }}\right.\right.$, haplotype $) \times 100]$. Haplotypes are presented as $\alpha_{s 1^{-}}, \beta-$, or $\kappa-\mathrm{CN}$.

\section{Yogurt Manufacture}

Yogurt samples with added sulla and chestnut honey, as well as the control (without any addition), were prepared. After being heat treated at $95^{\circ} \mathrm{C}$ for $15 \mathrm{~min}$ followed by cooling to $45^{\circ} \mathrm{C}$, all whole milk samples were inoculated at the same time with $1 \%$ (vol/vol) Strep. thermophilus and Lb. delbrueckii ssp. bulgaricus. Fermentation was carried out at $45^{\circ} \mathrm{C}$. Each fermentation process was monitored by continuous recording of $\mathrm{pH}$ values to measure the acidification rates during fermentation until the $\mathrm{pH}$ value reached $4.6 \pm 0.1$. Once the desired $\mathrm{pH}$ was reached, the sulla and chestnut honey $(30 \%$, wt $/ \mathrm{vol})$ were added and incorporated by mechanical stirring; consequently, the prepared product was a stirred type yogurt. Finally, yogurts were cooled at $4^{\circ} \mathrm{C}$ and stored for $24 \mathrm{~h}$ before analysis.

\section{Preparation of Water-Soluble Extracts of Control and Fortified Yogurt}

Yogurt samples were centrifuged at $5,000 \times g$ at $4^{\circ} \mathrm{C}$ for $20 \mathrm{~min}$. The supernatant was separately filtered through a membrane filter $(0.45 \mathrm{~nm})$ and was used to measure the antioxidant activity.

\section{Antioxidant Activity of ABTS Radical Scavenging Assay}

A modification of the original method of Re et al. (1999) was applied to assess the scavenging capacity of yogurt samples in a reaction with the ABTS radical. The ABTS radical solution was generated by oxidation of 2,2'-azino-bis(3-ethylbenzothiazoline-6-sulfonic acid) diammonium salt stock solution with potassium persulfate $\left(\mathrm{K}_{2} \mathrm{~S}_{2} \mathrm{O}_{8}\right)$. Stock solutions of ABTS $(7 \mathrm{mM})$ and potassium persulfate $(140 \mathrm{mM})$ were prepared in water and ABTS radical solution was produced by reacting $10 \mathrm{~mL}$ of the ABTS stock solution with $175 \mu \mathrm{L}$ of potassium persulfate solution. The mixture was left to stand in the dark at room temperature for 12 to 16 $\mathrm{h}$ before use. For the evaluation of antioxidant capacity, the ABTS solution was diluted with ethanol $(96 \%)$ to obtain the absorbance of $0.700 \pm 0.020$ at $734 \mathrm{~nm}$. Two milliliters of ABTS solution were mixed with $100 \mu \mathrm{L}$ of water-soluble extracts of yogurt in a cuvette and the decrease in the absorbance was measured after $30 \mathrm{~min}$. The reagent blank was prepared by adding $100 \mu \mathrm{L}$ of ethanol instead of the sample. The calibration curve was constructed using ascorbic acid $(2.2-0.25 \mu M)$ and the results were expressed as micrograms of ascorbic acid equivalents (AAE) per milliliter of extract.

\section{Determination of Antioxidant Activity by Ferric-Reducing Antioxidant Power}

The ferric-reducing antioxidant power (FRAP) assay was performed according to the procedure described by Benzie and Strain (1996) with some modifications. The FRAP reagent was prepared by mixing $10 \mathrm{~mL}$ of 300 $\mathrm{m} M$ acetate buffer (pH 3.6), $1 \mathrm{~mL}$ of $10 \mathrm{~m} M$ TPTZ in $40 \mathrm{mM} \mathrm{HCl}$, and $1 \mathrm{~mL}$ of $20 \mathrm{mM} \mathrm{FeCl}_{3}$ (in the ratio $10: 1: 1 \mathrm{vol} / \mathrm{vol} / \mathrm{vol}$ ). It was prepared daily and warmed to $37^{\circ} \mathrm{C}$ before use. Aliquots of $100 \mu \mathrm{L}$ of water-soluble extracts of samples were mixed with $2.9 \mathrm{~mL}$ of FRAP reagent and incubated at $37^{\circ} \mathrm{C}$ for $30 \mathrm{~min}$. The increase 
Table 1. Frequencies of the $\alpha_{\mathrm{S1}^{-}}, \beta-$, and $\kappa$-CN haplotypes in cow milk

\begin{tabular}{lllc}
\hline \multicolumn{3}{c}{ Haplotype } & \\
\hline$\alpha_{\mathrm{s} 1}-\mathrm{CN}$ & $\beta-\mathrm{CN}$ & $\kappa-\mathrm{CN}$ & $\begin{array}{c}\text { Frequency } \\
(\%)\end{array}$ \\
\hline $\mathrm{BB}$ & $\mathrm{A}^{2} \mathrm{~A}^{1}$ & $\mathrm{AA}$ & 20.83 \\
$\mathrm{BB}$ & $\mathrm{A}^{2} \mathrm{~A}^{2}$ & $\mathrm{BB}$ & 20.83 \\
$\mathrm{BB}$ & $\mathrm{A}^{2} \mathrm{~B}$ & $\mathrm{AB}$ & 16.67 \\
$\mathrm{BB}$ & $\mathrm{A}^{2} \mathrm{~A}^{1}$ & $\mathrm{AB}$ & 12.50 \\
$\mathrm{CC}$ & $\mathrm{A}^{2} \mathrm{~A}^{2}$ & $\mathrm{BB}$ & 12.50 \\
$\mathrm{BB}$ & $\mathrm{A}^{2} \mathrm{~A}^{2}$ & $\mathrm{AB}$ & 8.33 \\
$\mathrm{BB}$ & $\mathrm{A}^{2} \mathrm{~A}^{2}$ & $\mathrm{AA}$ & 8.33 \\
\hline
\end{tabular}

in absorbance was measured at $593 \mathrm{~nm}$ against acetate buffer ( $\mathrm{pH} 3.6)$. The blank reagent was prepared by adding distilled water instead of the sample. The calibration curve was constructed using ascorbic acid $(2.2-0.25 \mu M)$ and the results were expressed as micrograms of AAE per milliliter of extract.

The percentage change of antioxidant activity of fortified yogurt was determined by the formula

$$
\% \Delta=\left(\mathrm{AA}_{\mathrm{C}}-\mathrm{AA}_{\mathrm{YF}} / \mathrm{AA}_{\mathrm{C}}\right) \times 100,
$$

where $\% \Delta$ is the percentage change of antioxidant activity of fortified yogurt; $\mathrm{AA}_{\mathrm{C}}$ is the antioxidant activity value of control yogurt; and $\mathrm{AA}_{\mathrm{YF}}$ is the antioxidant activity value of fortified yogurt.

\section{Determination of Total Phenolic and Flavonoid Contents of Honey Samples}

The total phenolic content of honey was estimated according to the Folin-Ciocalteu method as modified by Beretta et al. (2005). Gallic acid (0-200 mg/L) was used as standard to derive the calibration curve and the results were expressed as milligrams of gallic acid equivalents per $100 \mathrm{~g}$ of honey. Total flavonoid content was determined using the Dowd method as adapted by Arvouet-Grand et al. (1994). Quercetin (0-200 mg/L) was used as standard to derive the calibration curve and the results were expressed as $\mathrm{mg}$ of quercetin equivalents per $100 \mathrm{~g}$ of honey.

\section{Statistical Analysis}

Data were analyzed according to the following linear model (SAS Institute, 1996):

$$
\mathrm{y}_{i j k}=\mu+\alpha_{i}+\beta_{j}+(\alpha \beta)_{i j}+\varepsilon_{i j k},
$$

where $\mathrm{y}_{i j k}$ is the observation; $\mu$ is the overall mean; $\alpha_{i}$ is the fixed effect of the $i$ th haplotype $(i=1,2,3$, $4,5,6,7) ; \beta_{j}$ is the fixed effect of the $j$ th honey $(j=$ $1,2) ;(\alpha \beta)_{i j}$ is the interaction of haplotype $\times$ honey; and $\varepsilon_{i j k}$ is the random error. Before setting the values, expressed as percentages, they were subjected to angular transformation. Student's $t$-test was used for all variable comparisons. Correlation between parameters was determined by Pearson correlation analysis.

\section{RESULTS}

\section{Haplotype Frequencies}

Seven different CN haplotypes were identified by isoelectric focusing. The different allelic combinations of loci $\alpha_{\mathrm{S1}^{-}}, \beta$-, and $\kappa_{-} \mathrm{CN}$ and their frequencies are reported in Table 1 . Haplotypes BB- $\mathrm{A}^{2} \mathrm{~A}^{1}-\mathrm{AA}, \mathrm{BB}-\mathrm{A}^{2} \mathrm{~A}^{2}$ $\mathrm{BB}(20.83 \%)$, and $\mathrm{BB}-\mathrm{A}^{2} \mathrm{~B}-\mathrm{AB}(16.67 \%)$ were frequent, whereas BB- $\mathrm{A}^{2} \mathrm{~A}^{2}-\mathrm{AA}$, BB- $\mathrm{A}^{2} \mathrm{~A}^{2}-\mathrm{AB}$, and $\mathrm{BB}-\mathrm{A}^{2} \mathrm{~A}^{2}-\mathrm{BB}$ showed the lowest frequency $(8.33 \%)$.

\section{Antioxidant Activity}

The ABTS and FRAP values of yogurt with different CN haplotypes, with and without (control) added honey, are reported in Tables 2 and 3. Statistical analysis showed a significant effect of the added honey and CN

\begin{tabular}{|c|c|c|c|c|c|c|c|c|}
\hline \multicolumn{3}{|c|}{ Haplotype } & \multicolumn{2}{|c|}{ Control } & \multicolumn{2}{|c|}{ Chestnut yogurt } & \multicolumn{2}{|c|}{ Sulla yogurt } \\
\hline$\alpha_{\mathrm{s} 1}-\mathrm{CN}$ & $\beta-\mathrm{CN}$ & $\kappa-\mathrm{CN}$ & Mean & $\mathrm{SD}$ & Mean & $\mathrm{SD}$ & Mean & $\mathrm{SD}$ \\
\hline $\mathrm{BB}$ & $\mathrm{A}^{2} \mathrm{~A}^{2}$ & $\mathrm{BB}$ & $199.30^{\mathrm{a}, \mathrm{A}}$ & 11.09 & $339.38^{\mathrm{a}, \mathrm{c}, \mathrm{B}}$ & 15.82 & $260.10^{\mathrm{a}, \mathrm{b}, \mathrm{C}}$ & 23.83 \\
\hline $\mathrm{BB}$ & $\mathrm{A}^{2} \mathrm{~A}^{1}$ & $\mathrm{AA}$ & $236.48^{\mathrm{b}, \mathrm{A}}$ & 18.81 & $325.26^{\mathrm{a}, \mathrm{d}, \mathrm{B}}$ & 14.82 & $252.08^{\mathrm{a}, \mathrm{A}}$ & 19.14 \\
\hline $\mathrm{BB}$ & $\mathrm{A}^{2} \mathrm{~A}^{2}$ & $\mathrm{AA}$ & $118.39^{\mathrm{c}, \mathrm{A}}$ & 17.46 & $287.58^{\mathrm{b}, \mathrm{B}}$ & 19.87 & $253.17^{\mathrm{a}, \mathrm{C}}$ & 18.26 \\
\hline $\mathrm{CC}$ & $\mathrm{A}^{2} \mathrm{~A}^{2}$ & $\mathrm{BB}$ & $169.72^{\mathrm{d}, \mathrm{A}}$ & 19.73 & $280.03^{\mathrm{b}, \mathrm{B}}$ & 34.63 & $213.50^{\mathrm{d}, \mathrm{C}}$ & 10.52 \\
\hline $\mathrm{BB}$ & $\mathrm{A}^{2} \mathrm{~A}^{1}$ & $\mathrm{AB}$ & $251.35^{\mathrm{e}, \mathrm{A}}$ & 12.93 & $329.16^{\mathrm{a}, \mathrm{B}}$ & 10.74 & $294.55^{\mathrm{c}, \mathrm{C}}$ & 18.5 \\
\hline $\mathrm{BB}$ & $\mathrm{A}^{2} \mathrm{~A}^{2}$ & $\mathrm{AB}$ & $196.96^{\mathrm{a}, \mathrm{A}}$ & 6.08 & $342.63^{\mathrm{c}, \mathrm{B}}$ & 2.84 & $270.94^{\mathrm{b}, \mathrm{C}}$ & 11.76 \\
\hline $\mathrm{BB}$ & $\mathrm{A}^{2} \mathrm{~B}$ & $\mathrm{AB}$ & $263.92^{\mathrm{e}, \mathrm{A}}$ & 20.20 & $312.38^{\mathrm{d}, \mathrm{B}}$ & 14.02 & $211.73^{\mathrm{d}, \mathrm{C}}$ & 6.56 \\
\hline
\end{tabular}

Table 2. Radical-scavenging activity of yogurts with different haplotypes, with and without added chestnut or sulla honey ${ }^{1}$

${ }^{\mathrm{A}-\mathrm{C}}$ Different uppercase superscripts depict the statistical difference within a row $(P<0.05)$ between means for different yogurt batches.

${ }^{\mathrm{a}-\mathrm{e}}$ Different lowercase letter superscripts depict the statistical difference within a column $(P<0.05)$ between means for the same yogurt batches at different casein haplotype.

${ }^{1}$ Measured using 2,2'-azino-bis-(3-ethylbenzothiazoline-6-sulfonic acid) assay and expressed as micrograms of ascorbic acid equivalents per milliliter. 
Table 3. Ferric-reducing antioxidant power of yogurts with different haplotypes, with and without added chestnut or sulla honey ${ }^{1}$

\begin{tabular}{|c|c|c|c|c|c|c|c|c|}
\hline \multicolumn{3}{|c|}{ Haplotype } & \multicolumn{2}{|c|}{ Control } & \multicolumn{2}{|c|}{ Chestnut yogurt } & \multicolumn{2}{|c|}{ Sulla yogurt } \\
\hline$\overline{\mathrm{BB}}$ & $\mathrm{A}^{2} \mathrm{~A}^{2}$ & BB & $113.40^{\mathrm{a}, \mathrm{A}}$ & 32.27 & $231.01^{\mathrm{a}, \mathrm{c}, \mathrm{B}}$ & 19.55 & $156.78^{\mathrm{a}, \mathrm{b}, \mathrm{C}}$ & 34.44 \\
\hline $\mathrm{BB}$ & $\mathrm{A}^{2} \mathrm{~A}^{2}$ & $\mathrm{AA}$ & $91.63^{\mathrm{a}, \mathrm{A}}$ & 7.59 & $292.98^{\mathrm{b}, \mathrm{B}}$ & 32.08 & $178.20^{\mathrm{a}, \mathrm{b}, \mathrm{C}}$ & 31.67 \\
\hline $\mathrm{CC}$ & $\mathrm{A}^{2} \mathrm{~A}^{2}$ & $\mathrm{BB}$ & $95.87^{\mathrm{a}, \mathrm{A}}$ & 3.71 & $246.18^{\mathrm{c}, \mathrm{e}, \mathrm{B}}$ & 21.47 & $145.14^{\mathrm{a}, \mathrm{C}}$ & 15.77 \\
\hline $\mathrm{BB}$ & $\mathrm{A}^{2} \mathrm{~A}^{1}$ & $\mathrm{AB}$ & $141.78^{\mathrm{b}, \mathrm{A}}$ & 24.31 & $130.58^{\mathrm{d}, \mathrm{B}}$ & 3.48 & $180.87^{\mathrm{b}, \mathrm{C}}$ & 10.38 \\
\hline
\end{tabular}

${ }^{\mathrm{A}-\mathrm{C}}$ Different uppercase superscripts depict the statistical difference within a row $(P<0.05)$ between means for different yogurt batches.

${ }^{\mathrm{a}-\mathrm{e}}$ Different lowercase superscripts depict the statistical difference within a column $(P<0.05)$ between means for the same yogurt batches at different casein haplotype.

${ }^{1}$ The values are expressed as micrograms of ascorbic acid equivalents per milliliter.

haplotype on the antioxidant activity of yogurt $(P<$ 0.001). The antioxidant activity of the control sample showed different values as a function of the CN haplotype. The average ABTS value was $204.43 \pm 57.81 \mu \mathrm{g}$ of $\mathrm{AAE} / \mathrm{mL}$, which increased in the order of $\mathrm{BB}-\mathrm{A}^{2} \mathrm{~A}^{2}-\mathrm{AA}$ $<$ CC- $\mathrm{A}^{2} \mathrm{~A}^{2}-\mathrm{BB}<\mathrm{BB}-\mathrm{A}^{2} \mathrm{~A}^{2}-\mathrm{AB}<\mathrm{BB}-\mathrm{A}^{2} \mathrm{~A}^{2}-\mathrm{BB}<\mathrm{BB}-$ $\mathrm{A}^{2} \mathrm{~A}^{1}-\mathrm{AA}<\mathrm{BB}-\mathrm{A}^{2} \mathrm{~A}^{1}-\mathrm{AB}<\mathrm{BB}-\mathrm{A}^{2} \mathrm{~B}-\mathrm{AB}$ (Table 2). The average FRAP value was $116.74 \pm 29.3 \mu \mathrm{g}$ of AAE/ $\mathrm{mL}$ and the increasing sequence of radical scavenging was $\mathrm{BB}-\mathrm{A}^{2} \mathrm{~A}^{2}-\mathrm{AA}<\mathrm{CC}-\mathrm{A}^{2} \mathrm{~A}^{2}-\mathrm{BB}<\mathrm{BB}-\mathrm{A}^{2} \mathrm{~A}^{2}-\mathrm{BB}<$ BB-A $\mathrm{A}^{2} \mathrm{~B}-\mathrm{AB}<\mathrm{BB}-\mathrm{A}^{2} \mathrm{~A}^{2}-\mathrm{AB}<\mathrm{BB}-\mathrm{A}^{2} \mathrm{~A}^{1}-\mathrm{AB}<\mathrm{BB}-$ $\mathrm{A}^{2} \mathrm{~A}^{1}$-AA (Table 3 ). In particular, the control sample with the haplotype $\mathrm{BB}-\mathrm{A}^{2} \mathrm{~A}^{2}-\mathrm{AA}$ showed the lowest radical scavenging activity, whereas the control sample with the haplotype $\mathrm{BB}-\mathrm{A}^{2} \mathrm{~A}^{1}-\mathrm{AA}, \mathrm{BB}-\mathrm{A}^{2} \mathrm{~A}^{1}-\mathrm{AB}$ and $\mathrm{BB}-\mathrm{A}^{2} \mathrm{~B}-\mathrm{AB}$ showed the highest value in both assays.

The chestnut and sulla honeys were used to fortify yogurt in our study. Total phenol, total flavonoid, ABTS, and FRAP values of the studied honey are reported in Table 4. Darker honey, such as chestnut honey, tends to have higher antioxidant properties than lighter ones (Gheldof et al., 2002). Total phenolic and flavonoid contents were higher in chestnut honey, around 2.5 times more than those found in sulla honey (18.6 vs. $7.23 \mathrm{mg}$ of gallic acid equivalents $/ 100 \mathrm{~g}$ and 5.15 vs. $1.95 \mathrm{mg}$ of quercetin equivalents/100 g for total phenolic and flavonoid contents, respectively). The values found in studied samples match the results reported by other authors for chestnut and sulla honey (Bertoncelj et al., 2007; Pichichero et al., 2009; Perna et al., 2012). Chest- nut honey presented the greater antioxidant activity in both assays. The findings confirm what has been found in previous studies by Perna et al. (2012), which highlighted a close correlation between antioxidant activity and polyphenol content.

Yogurts with added honey showed an increase of the antioxidant activity compared with control (Table 2 and 3). In particular, yogurts with added chestnut honey showed higher ABTS and FRAP values than the yogurts with added sulla honey. Among the yogurt with added chestnut honey, the one with the haplotype $\mathrm{BB}-\mathrm{A}^{2} \mathrm{~A}^{2}-\mathrm{AB}$ showed the highest radical scavenging activity $(342.63 \mu \mathrm{g}$ of $\mathrm{AAE} / \mathrm{mL})$, whereas that with the haplotype $\mathrm{CC}-\mathrm{A}^{2} \mathrm{~A}^{2}-\mathrm{BB}$ showed the lowest value (280.03 $\mu \mathrm{g}$ of AAE/mL; Table 3 ); chestnut yogurt with the haplotype $\mathrm{BB}-\mathrm{A}^{2} \mathrm{~A}^{2}-\mathrm{AA}$ showed the highest FRAP value $(292.98 \mu \mathrm{g}$ of $\mathrm{AAE} / \mathrm{mL})$, whereas that with the haplotype $\mathrm{BB}-\mathrm{A}^{2} \mathrm{~A}^{1}-\mathrm{AB}$ showed the lowest value (130.58 ug of AAE $/ \mathrm{mL} ; P<0.05)$. Among the yogurt with added sulla honey, the one with the haplotype $\mathrm{BB}-\mathrm{A}^{2} \mathrm{~A}^{1}-\mathrm{AB}$ showed the highest $\mathrm{ABTS}$ value, whereas that made with the haplotype $\mathrm{BB}-\mathrm{A}^{2} \mathrm{~B}-\mathrm{AB}$ showed the lowest value $(211.73 \mu \mathrm{g}$ of $\mathrm{AAE} / \mathrm{mL})$; sulla yogurt with the haplotype $\mathrm{CC}-\mathrm{A}^{2} \mathrm{~A}^{2}$-BB showed the lowest FRAP value $(145.14 \mu \mathrm{g}$ of $\mathrm{AAE} / \mathrm{mL})$ and that with the haplotype $\mathrm{BB}-\mathrm{A}^{2} \mathrm{~A}^{2}-\mathrm{AB}$ showed the highest value (186.16 $\mu \mathrm{g}$ of $\mathrm{AAE} / \mathrm{mL}$ ).

The percentage change of antioxidant activity $(\Delta \%)$ highlights the effect of the added depending on the haplotype and type of honey and is reported in Fig-

Table 4. Total phenolic and flavonoid contents and antioxidant activity of honey samples from different botanical origins

\begin{tabular}{|c|c|c|}
\hline \multirow[b]{2}{*}{ Item } & \multicolumn{2}{|c|}{ Honey } \\
\hline & Chestnut & Sulla \\
\hline Total phenolic (mg of gallic acid equivalents/100 g) & 18.6 & 7.23 \\
\hline Total flavonoid ( $\mathrm{mg}$ of quercetin equivalents $/ 100 \mathrm{~g}$ ) & 5.15 & 1.95 \\
\hline 2,2 -azino-bis-(3-ethylbenzothiazoline-6-sulfonic acid) ( $\mu \mathrm{g}$ of ascorbic acid equivalents $/ \mathrm{mL}$ ) & 359.55 & 252.31 \\
\hline Ferric-reducing antioxidant power ( $\mu \mathrm{g}$ of ascorbic acid equivalents $/ \mathrm{mL}$ ) & 253.29 & 92.88 \\
\hline
\end{tabular}


ures 1 and 2. The addition of chestnut honey resulted in an increase of the antioxidant activity of yogurt, evaluated by ABTS assay, showing a mean increase of $54.33 \%$, with a variation from $18.36 \%$ (yogurt with the haplotype BB-A ${ }^{2} \mathrm{~B}-\mathrm{AB}$ ) to $142.90 \%$ (yogurt with the haplotype $\left.\mathrm{BB}-\mathrm{A}^{2} \mathrm{~A}^{2}-\mathrm{AA}\right)$. Considering the FRAP assay, the effect of the addition of chestnut honey showed a significant increase in antioxidant activity in almost all yogurts. The average increase of antioxidant activity was $100.6 \%$, with a variation from $46.79 \%$ (yogurt with the haplotype BB-A ${ }^{2} \mathrm{~A}^{1}-\mathrm{AA}$ ) to $219.76 \%$ (yogurt with the haplotype $\left.\mathrm{BB}-\mathrm{A}^{2} \mathrm{~A}^{2}-\mathrm{AA}\right)$. Chestnut yogurt with the haplotype $\mathrm{BB}-\mathrm{A}^{2} \mathrm{~A}^{1}-\mathrm{AB}$ showed a decrease in antioxidant activity, about of $-7.90 \%$ compared to the control. The antioxidant activity of yogurt with added sulla honey, measured by ABTS assay, showed a mean increase of $22 \%$, with values that ranged from $6.60 \%$ (yogurt with the haplotype BB- $\mathrm{A}^{2} \mathrm{~A}^{1}-\mathrm{AA}$ ) to $113.84 \%$ (yogurt with the haplotype $\mathrm{BB}-\mathrm{A}^{2} \mathrm{~A}^{1}-\mathrm{AA}$ ). The yogurt with the haplotype $\mathrm{BB}-\mathrm{A}^{2} \mathrm{~B}-\mathrm{AB}$ showed a decrease of $-19.77 \%$ compared to the control. The mean percentage increase of antioxidant activity detected in the yogurt with added sulla honey, evaluated by FRAP assay, was $44 \%$, with values that ranged between $94.48 \%$ (yogurt with the haplotype $\mathrm{BB}-\mathrm{A}^{2} \mathrm{~A}^{2}-\mathrm{AA}$ ) and $12.87 \%$ (yogurt with the haplotype $\left.\mathrm{BB}-\mathrm{A}^{2} \mathrm{~A}^{1}-\mathrm{AA}\right)$.

\section{DISCUSSION}

The lack of a widely accepted standardized method for evaluation of antioxidant properties of foods and the complex reactivity of bioactive compounds are the reason why we employed 2 different antioxidant capacity assays (Schlesier et al., 2002). The ABTS assay is one of the most widely used methods for the screening of antioxidant activity, as it measures the scavenging activity of several natural products and it is applicable to both hydrophilic and lipophilic antioxidant systems (Re et al., 1999). The FRAP assay is considered as a useful indicator of the antioxidant status to counteract the oxidative damage due to reactive oxygen species (Küçük et al., 2007), and it uses antioxidants as reductants in a redox-linked colorimetric method, employing an easily reduced oxidant system present in stoichiometric excess.

Yogurt itself has a large antioxidant capacity, related to the presence of different bioactive peptides from milk proteins through proteolysis by LAB (Kudoh et al., 2001; Virtanen et al., 2007; Gomez-Ruiz et al., 2008). The antioxidant capacity is also conditioned by the heat treatment undergone by the milk for the manufacture of the yogurt (Galleher et al., 2005), by the fermentation and postacidification during storage that determine production of organic acids (Correia et al., 2004),

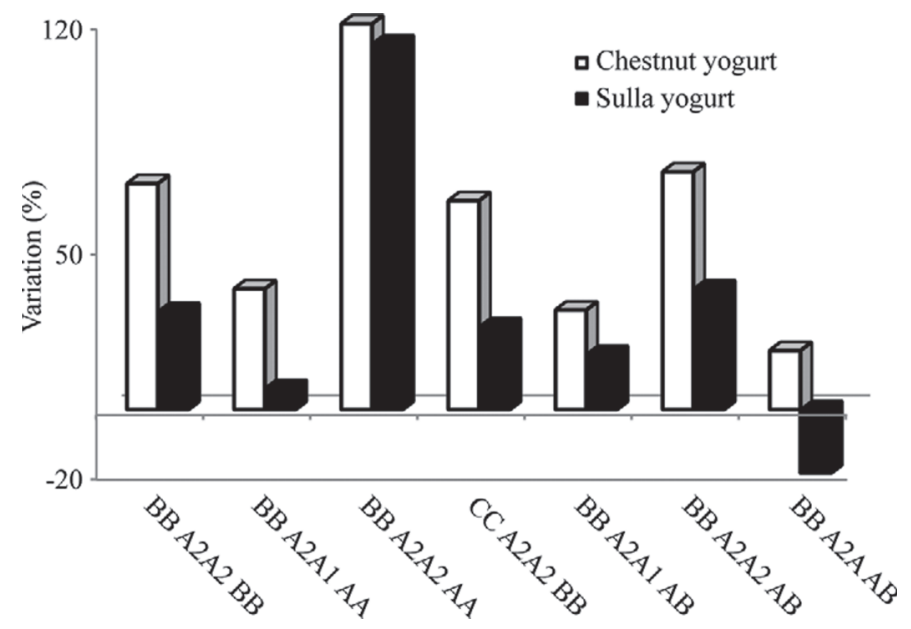

Figure 1. Percentage change of antioxidant activity of yogurt made from milk characterized by different casein haplotypes and fortified with honey than the control sample, measured using 2,2'-azino-bis-(3ethylbenzothiazoline-6-sulfonic acid) assay and expressed as micrograms of ascorbic acid equivalents per milliliter of extract.

and by possible aggregation of peptide processes that occur during the enzymatic hydrolysis of whey protein and CN (Adt et al., 2011). In a previous study, Perna et al. (2013a) demonstrated that yogurts made from cow milk characterized by different CN haplotypes showed different antioxidant activity due to the specific amino acid sequence of the milk protein variants. HernándezLedesma et al. (2005) showed that peptides released from the $\mathrm{A}$ variant of $\beta-\mathrm{LG}$ are small ( $3 \mathrm{kDa}$ ) and are mainly responsible for antioxidant activity compared with the $\mathrm{AB}$ variant of $\beta-\mathrm{LG}$.

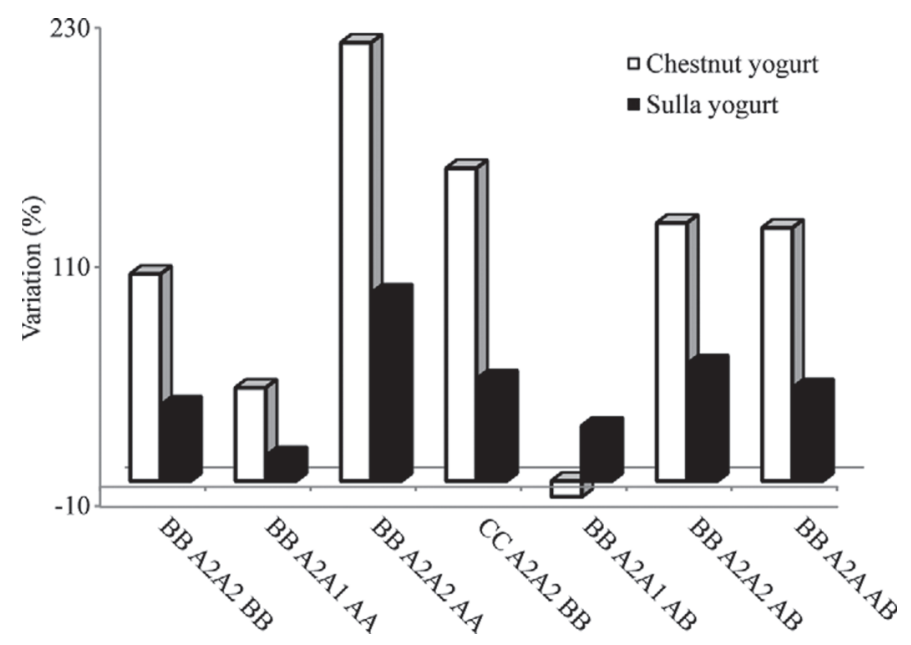

Figure 2. Percentage change of antioxidant activity of yogurt made from milk characterized by different casein haplotypes and fortified with honey than the control sample, measured by ferric-reducing antioxidant power assay and expressed as micrograms of ascorbic acid equivalents per milliliter of extract. 
In the current work, we observed that the antioxidant activity of fortified yogurt is also affected strongly by the type of honey. In fact, the same yogurt sample showed different values as a function of the type of honey added. The addition of chestnut honey to yogurt resulted in a greater increase of the antioxidant activity compared with the addition of sulla honey. This could be due to the higher levels of phenolic acids and flavonoids found in the chestnut honey compared with sulla honey; in fact, these honey showed quantitatively and qualitatively different phenolic profiles (Perna et al., 2013b). Honey from different floral sources possess strong antioxidative activities and are strong reactive oxygen species scavengers (Beretta et al., 2005; Perna et al., 2012). Among the main factors responsible for the biological and nutraceutical activities, phenolic substances of honey have a key role (Al-Mamary et al., 2002; Aljadi and Kamaruddin, 2004). Also, it has been observed that the increase or decrease of antioxidant capacity of yogurts after the addition of honey is closely linked to the different $\mathrm{CN}$ haplotype. Prigent et al. (2003) demonstrated that the effect of the interaction between milk protein or peptides and phenolic compounds on antioxidant activity depends on both amino acid composition of proteins and type of phenols. The bond between polyphenol and protein is not identical, and 4 potential types of interactions exist between phenolic metabolites and proteins: hydrogen, hydrophobic, ionic, and covalent bonding (Hagerman et al., 1998; Rawel et al., 2002). The phenolic hydroxyl group is an excellent hydrogen bond donor and forms strong hydrogen bonds with the amide carbonyl of the peptide backbone (Luck et al., 1994; O'Connell and Fox, 2001). Many authors (Poncet-Legrand et al., 2006; Richard et al., 2006; Soares et al., 2007; Frazier et al., 2010) have reported that proline-rich proteins have a particularly high affinity for polyphenols. Dickinson and Mann (2006), using single molecule atomic force microscopy, showed that the protein wraps itself around the polyphenol by forming hydrophobic interactions between aromatic phenolic rings and proline residues. Caseins contain high numbers of proline residues evenly distributed throughout their amino acid sequences, they have relatively open structures, and are avid binders of polyphenols (Jöbstl et al., 2004; Pascal et al., 2008; Yan et al., 2009). Kartsova and Alekseeva (2008) reported that catechins bind strongest to the caseins, according to the order $\beta-\mathrm{CN}>\alpha-\mathrm{CN}>\kappa-\mathrm{CN}$, followed by whey proteins, namely $\alpha-\mathrm{LA}, \beta-\mathrm{LG}$, and BSA. The milk protein polymorphism affects the amino acid composition of protein; the $\mathrm{A}^{2}$ variant of $\beta$-CN differs from the $\mathrm{A}^{1}$ variant because it has a Pro residue instead of a His residue (Korhonen and Marnila, 2013), which could explain the enhanced ability to interact with phenolic compounds. Likewise, in yogurt, the nitrogen fraction is composed of whole protein and peptides, obtained after proteolysis, which are characterized by reactive sites able to bind with different compounds, such as polyphenols. These protein-polyphenol complexes can reduce or enhance antioxidant activity. The different behavior observed among fortified yogurts led us to hypothesize that effects of protein-polyphenol complex on antioxidant activity are interactive, in agreement with that found by Arts et al. (2002). Those authors reported that the antioxidant capacity of the interaction between polyphenols and proteins is lower than the sum of the antioxidant capacity of individual components. The protein-polyphenol complexes could have effects in terms of bioavailability (Serafini et al., 1996), as the antioxidant activity of polyphenols could be modified by the presence of proteins (Arts et al., 2002).

\section{CONCLUSIONS}

This study highlights the complex dynamic actions that occur when foods with different biochemical characteristics interact. We demonstrate that milk protein polymorphisms and polyphenols play different roles in affecting the bioavailability and the antioxidant activity of yogurt. More in-depth mechanisms will require clarification in future investigations to identify the possible combination between casein haplotype and honey that can lead to the manufacture of yogurt formulations with specific nutraceutical properties.

\section{REFERENCES}

Abd El-Rahman, H. A., and W. M. Salama. 2008. Preparation of yoghurt-like products with safflower as a substitution material. Egypt. J. Dairy Sci. 36:39-44.

Adt, I., C. Dupas, R. Boutrou, N. Oulahal, C. Noel, and D. Mollé. 2011. Identification of caseinophosphopeptides generated through in vitro gastro-intestinal digestion of Beaufort cheese. Int. Dairy J. 21:129-134.

Al-Mamary, M., A. Al-Meeri, and M. Al-Habori. 2002. Antioxidant activities and total phenolics of different types of honey. Nutr. Res. 22:1041-1047.

Aljadi, A. M., and M. Y. Kamaruddin. 2004. Evaluation of the phenolic contents and antioxidant capacities of two Malaysian floral honeys. Food Chem. 85:513-518.

Arts, M. J., G. R. Haenen, L. C. Wilms, S. A. Beetstra, C. G. Heijne, H. P. Voss, and A. J. Bast. 2002. Interactions between flavonoids and proteins: Effect on the total antioxidant capacity. J. Agric. Food Chem. 50:1184-1187.

Arvouet-Grand, A., B. Vennat, A. Pourrat, and P. Legret. 1994. Standardisation d'un extrait de propolis et identification des principaux constituants. J. Pharm. Belg. 49:462-468.

Aschaffenburg, R., and J. Drewry. 1959. New procedure for the routine determination of the various non-casein proteins of milk. Pages 1631-1637 in 15th Int. Dairy Congr., London, UK. Vol. 3. Richard Clay and Co. Ltd., Bungay, Suffolk, UK.

Benzie, I. F., and J. J. Strain. 1996. The ferric reducing ability of plasma (FRAP) as a measure of "antioxidative activity of extracts from selected species of the antioxidant power": The FRAP assay. Anal. Biochem. 239:70-76. 
Beretta, G., P. Granata, M. Ferrero, M. Orioli, and R. Maffei Facino. 2005. Standardization of antioxidant properties of honey by combination of spectrophotometric/fluorimetric assays and chemometrics. Anal. Chim. Acta 533:185-191.

Bertoncelj, J., U. Doberšek, M. Jamnik, and T. Golob. 2007. Evaluation of the phenolic content, antioxidant activity and colour of Slovenian honey. Food Chem. 105:822-828.

Bills, D., C. S. Yang, M. E. Morgan, and F. W. Bodyfelt. 1972. Effect of sucrose on the production of acetaldehyde and acids by yogurt culture bacteria. J. Dairy Sci. 55:1570-1573.

Blakesley, R. W., and J. A. Boezi. 1977. A new staining technique for proteins in polyacrylamide gels using Comassie Brilliant Blue G250. Anal. Biochem. 82:580-582.

Blasa, M., M. Candiracci, A. Accorsi, M. P. Piacentini, M. C. Albertini, and E. Piatti. 2006. Raw Millefiori honey is packed full of antioxidants. Food Chem. 97:217-222.

Chick, H., H. S. Shin, and Z. Ustunol. 2001. Growth and acetic production by lactic acid bacteria and bifidobacteria grown in skim milk containing honey. J. Food Sci. 66:478-481.

Colbert, L. B., and E. A. Decker. 1991. Antioxidant activity of an ultrafiltration permeate from acid whey. J. Food Sci. 56:1248-1250.

Correia, I., A. Nunes, I. F. Duarte, A. Barros, and I. Elgadillo. 2004. Sorghum fermentation followed by spectroscopic techniques. Food Chem. 90:853-859.

Čurda, L., and M. Plocková. 1995. Impedance measurement of growth of lactic acid bacteria in dairy cultures with honey addition. Int. Dairy J. 5:727-733.

Dickinson, M. E., and A. B. Mann. 2006. Nanomechanics and morphology of salivary pellicle. J. Mater. Res. 21:1996-2002.

DIN. 2002. Analysis of Honey-Determination of the Relative Frequency of Pollen. German Institute for Standardization, Berlin, Germany.

El-Baz, A. M., and M. A. Zommara. 2007. Characteristics of carbonated stirred yoghurt-bifidum milk fortified with honey and vitamin C. Egypt. J. Dairy Sci. 35:45-56.

Ezz El-Arab, A. M., S. M. Girgis, E. M. Hegazy, and A. B. Abd ElKhalek. 2006. Effect of dietary honey on intestinal microflora and toxicity of mycotoxins in mice. BMC Complement. Altern. Med. 6:6.

Frazier, R. A., E. R. Deaville, R. J. Green, E. Stringano, I. Willoughby, J. Plant, and I. Mueller-Harvey. 2010. Interactions of tea tannins and condensed tannins with proteins. J. Pharm. Biomed. Anal. $51: 490-495$.

Galleher, J. J., R. Hollender, D. G. Peterson, R. F. Roberts, and J. N. Coupland. 2005. Effect of composition and antioxidants on the oxidative stability of fluid milk supplemented with an algae oil emulsion. Int. Dairy J. 15:333-341.

Gheldof, N., X. H. Wang, and N. J. Engeseth. 2002. Identification and quantification of antioxidant components of honey from various floral sources. J. Agric. Food Chem. 50:5870-5877.

Gheldof, N., and N. J. Engeseth. 2002. Antioxidant capacity of honeys from various floral sources based on the determination of oxygen radical absorbance capacity and inhibition of in vitro lipoprotein oxidation in human serum samples. J. Agric. Food Chem. 50:3050-3055.

Gomez-Ruiz, J., I. Lopez-Exposito, A. Pihlanto, M. Ramos, and I. Recio. 2008. Antioxidant activity of ovine casein hydrolysates: Identification of active peptides by HPLC-MS/MS. Eur. Food Res. Technol. 227:1061-1067.

Gupta, A., B. Mann, R. Kumar, and R. Sangwan. 2009. Antioxidant activity of Cheddar cheeses at different stages of ripening. Int. J. Dairy Technol. 62:339-347.

Hagerman, A. E., M. E. Rice, and N. T. Ritchard. 1998. Mechanisms of protein precipitation for two tannins pentagalloyl glucose and epicatechin $16(4 \rightarrow 8)$ catechin (procyanidin). J. Agric. Food Chem. 46:2590-2595.

Hernández-Ledesma, B., B. Miralles, L. Amigo, M. Ramos, and I. Recio. 2005. Identification of antioxidant and ACE-inhibitory peptides in fermented milk. J. Sci. Food Agric. 85:1041-1048.
Jöbstl, E., J. O'Connell, J. P. A. Fairclough, and M. P. Williamson. 2004. Molecular model for astringency produced by polyphenol/ protein interactions. Biomacromolecules 5:942-949.

Kagan, J. 1985. Yoghurt-A rising star in the dairy industry. Cult. Dairy Prod. J. 20:24-29.

Kartsova, L. A., and A. V. Alekseeva. 2008. Effect of milk caseins on the concentration of polyphenolic compounds in tea. J. Anal. Chem. 63:1107-1111.

Korhonen, H. J., and P. Marnila. 2013. Milk bioactive proteins and peptides. Pages 148-171 in Milk and Dairy Products in Human Nutrition: Production, Composition and Health. Y. W. Park and G. F. W. Heanlein, ed. John Wiley \& Sons, Oxford, UK.

Küçük, M., S. Kolayli, S. Karaoğlu, E. Ulusoy, C. Baltaci, and F. Candan. 2007. Biological activities and chemical composition of three honeys of different types from Anatolia. Food Chem. 100:526-534.

Kudoh, Y., S. Matsuda, K. Igoshi, and T. Oki. 2001. Antioxidative peptide from milk fermented with Lactobacillus delbrueckii ssp. bulgaricus IFO 13953. Nippon Shokuhin Kagaku Kogaku Kaishi 48:44-50. http://dx.doi.org/10.3136/nskkk.48.44.

Luck, G., H. Liao, N. J. Murray, H. R. Grimmer, E. E. Warminski, M. P. Williamson, T. H. Lilley, and E. Haslam. 1994. Polyphenols, astringency and proline-rich proteins. Phytochemistry 37:357-371.

Meda, A., C. E. Lamien, M. Romito, J. Millogo, and O. G. Nacoulma. 2005. Determination of the total phenolic, flavonoid and proline contents in Burkina Fasan honey, as well as their radical scavenging activity. Food Chem. 91:571-577.

Minervini, F., F. Algaron, G. C. Rizello, P. F. Fox, V. Monnet, and M. Gobbetti. 2003. Angiotensin I-converting-enzyme-inhibitory and antibacterial peptides from Lactobacillus helveticus PR4 proteinase-hydrolyzed caseins of milk from six species. Appl. Environ. Microbiol. 69:5297-5305.

Mundo, M. A., O. I. Padilla-Zakour, and R. W. Worobo. 2004. Growth inhibition of food-borne pathogens and food spoilage organisms by select raw honeys. Int. J. Food Microbiol. 97:1-8.

O'Connell, J. E., and P. E. Fox. 2001. Significance and applications of phenolic compounds in the production and quality of milk and dairy products. A review. Int. Dairy J. 11:103-120.

Orsolic, N., S. Terzic, L. Sver, and I. Basic. 2005. Honey-bee products in prevention and/or therapy of murine transplantable tumours. J. Agric. Food Chem. 85:363-370.

Pascal, C., C. Poncet-Legrand, B. Cabane, and A. Vernhet. 2008. Aggregation of a proline-rich protein induced by epigallocatechin gallate and condensed tannins: Effect of protein glycosylation. J. Agric. Food Chem. 56:6724-6732.

Pattorn, S., Y. Horimoto, P. Hongsprabhas, and R. Y. Yada. 2012. Influence of aggregation on the antioxidative capacity of milk peptides. Int. Dairy J. 25:3-9.

Perna, A., I. Intaglietta, A. Simonetti, and E. Gambacorta. 2013a. Effect of genetic type and casein haplotype on antioxidant activity of yogurts during storage. J. Dairy Sci. 96:3435-3441.

Perna, A., I. Intaglietta, A. Simonetti, and E. Gambacorta. 2013b. A comparative study on phenolic profile, vitamin C content and antioxidant activity of Italian honeys of different botanical origin. Int. J. Food Sci. Technol. 48:1899-1908.

Perna, A., A. Simonetti, I. Intaglietta, A. Sofo, and E. Gambacorta. 2012. Metal content of southern Italy honey of different botanical origins and its correlation with polyphenol content and antioxidant activity. Int. J. Food Sci. Technol. 47:1909-1917.

Peterson, J., and J. Dwyer. 1998. Flavonoids: Dietary occurrence and biochemical activity. Nutr. Res. 18:1995-2018.

Pichichero, E., L. Canuti, and A. Canini. 2009. Characterisation of the phenolic and flavonoids fractions and antioxidant power Italian of honeys of different botanical origin. J. Sci. Food Agric. 89:609-616.

Poncet-Legrand, C., A. Edelmann, J. L. Putaux, D. Cartalade, P. Sarni-Manchadoa, and A. Vernhet. 2006. Poly(L-proline) interactions with flavan-3-ols units: Influence of the molecular structure and the polyphenol/protein ratio. Food Hydrocoll. 20:687-697. 
Prigent, S. V. E., H. Gruppen, A. J. W. G. Visser, G. A. Van Koningsveld, G. A. H. de Jong, and A. G. J. Voragen. 2003. Effects of non-covalent interactions with 5-O (ortho)-caffeoylquinic acid (chlorogenic acid) on the heat denaturation and solubility of globular proteins. J. Agric. Food Chem. 51:5088-5095.

Rawel, H. M., D. Czajka, S. Rohn, and J. Kroll. 2002. Interactions of different phenolic acids and flavonoids with soy proteins. Int. J. Biol. Macromol. 30:137-150.

Re, R., N. Pellegrini, A. Proteggente, A. Pannola, M. Yang, and C. Rice-Evans. 1999. Antioxidant activity applying en improved ABTS radical cation decolorization assay. Free Radic. Biol. Med. 26:1231-1237.

Richard, T., D. Lefeuvre, A. Descendit, S. Quideau, and J. P. Monti 2006. Recognition characters in peptide-polyphenol complex formation. Biochim. Biophys. Acta 1760:951-958.

Rival, S. G., C. G. Boeriu, and H. J. Wichers. 2001. Caseins and casein hydrolysates. Antioxidative properties and relevance to lipoxygenase inhibition. J. Agric. Food Chem. 49:295-302.

Robards, K., P. D. Prenzler, G. Tucker, P. Swatsitang, and W. Glover. 1999. Phenolic compounds and their role in oxidative processes in fruits. Food Chem. 66:401-436.

Robinson, R. K. 2003.Yoghurt types and manufacture. Pages 10551059 in Encyclopedia of Dairy Science. Vol. 2. H. Roginski, J. W. Frquay and P. F. Fod, ed. Academic Press and Elsevier Science. Amsterdam, the Netherlands.

Roumyan, N., P. Zapryanov, and S. Kondareva. 1996. On some aspects of a new fermented milk product medina. Biotechnol., Biotechnol. Equip. 10:86-89.

Ryhanen, E. L., L. A. Pihlanto, and E. Pahkala. 2001. A new type of ripened low-fat cheese with bioactive properties. Int. Dairy J. 11:441-447.

Sanz, M. L., N. Polemis, V. Morales, N. Corzo, A. Drakoularakou, G. R. Gibson, and R. A. Rastall. 2005. In vitro investigation into the potential prebiotic activity of honey oligosaccharides . J. Agric. Food Chem. 53:2914-2921.

SAS Institute. 1996. SAS User's Guide: Statistics. ver. 7. SAS Institute Inc., Cary, NC.

Schlesier, K., M. Harwat, V. Bohm, and R. Bitsch. 2002. Assessment of antioxidant activity by using different in vitro methods. Free Radic. Res. 36:177-187.
Serafini, M., A. Ghiselli, and A. Ferro-Luzzi. 1996. In vivo antioxidant effect of green and black tea in man. Eur. J. Clin. Nutr. 50:28-32.

Soares, S., N. Mateus, and V. de Freitas. 2007. Interaction of different polyphenols with bovine serum albumin (BSA) and human salivary-amylase (HSA) by fluorescence quenching. J. Agric. Food Chem. 55:6726-6735.

Tong, L. M., S. Sasaki, D. J. McClements, and E. A. Decker. 2000. Mechanism of the antioxidant activity of high molecular weight fraction of whey. J. Agric. Food Chem. 48:1473-1478.

Tonks, A., R. A. Cooper, A. J. Price, P. C. Molan, and K. P. Jones. 2001. Stimulation of TNF-a release in monocytes by honey. $\mathrm{Cy}$ tokine 14:240-242.

Trieu-Cuot, P., and J. C. Gripon. 1981. Electrofocusing and two dimensional electrophoresis of bovine caseins. J. Dairy Res. 48:303310.

Ustunol, Z., and H. Gandhi. 2001. Growth and viability of commercial Bifidobacterium spp. on honey sweetened skim milk. J. Food Prot. 64:1775-1779.

Varga, L. 2006. Effect of acacia (Robinia pseudo-acacia L.) honey on the characteristic microflora of yogurt during refrigerated storage. Short communication. Int. J. Food Microbiol. 108:272-275.

Virtanen, T., A. Pihlanto, S. Akkanen, and H. Korhonen. 2007. Development of antioxidant activity in milk whey during fermentation with lactic acid bacteria. J. Appl. Microbiol. 102:106-115.

Von der Ohe, W., L. Persano Oddo, M. L. Piana, M. Morlot, and P. Martin. 2004. Harmonized methods of melissopalynological analysis. Apidologie (Celle) 35:18-25.

White, J. W. 1979. Composition of honey. Pages 157-158 in Honey: A Comprehensive Survey. E. Crane, ed. Heinemann, London, UK.

Wollgast, J., and E. Anklam. 2000. Review on polyphenols in theobroma cacao: Changes in composition during the manufacture of chocolate and methodology for identification and quantification. Food Res. Int. 33:423-447.

Yan, Y., J. Hu, and P. Yao. 2009. Effects of casein, ovalbumin, and dextran on the astringency of tea polyphenols determined by quartz crystal microbalance with dissipation. Langmuir 25:397-402. 